\title{
Climate Change as a Driver of Covid-19: The Protection of Refugees in the Post Covid-19 World
}

\author{
Palmer Prince Dagadu ${ }^{1 *}$ Kujo Elias McDave ${ }^{2}$ Elizabeth Yongyeh Ngalim ${ }^{3}$ \\ 1. Ph.D. Candidate in International Law, School of Law, Xiamen University, China \\ 2. Dean. Faculty of Law, Pentecost University, Ghana \\ 3. Ph.D. Candidate in International Law, School of Law and Economics, Zhengzhou University, China \\ *E-mail of the corresponding author: palmerdagadu@outlook.com
}

\begin{abstract}
As the world is grappling with the chaos brought about by COVID-19, coupled with already existing climate change situation, the global refugee crisis is predicted to worsen in the coming years. The impacts of climate change contribute to the increased vulnerability of disadvantaged communities to COVID-19. Exposure to environmental pollutants is strongly associated with increased risk and severity of COVID-19, as well as to preexisting health conditions that predispose to worse health outcomes in individuals infected with SARS-CoV2.Meanwhile, to mitigate the global refugee crisis during and in the post Covid 19 era, policymakers in different countries and international organizations have implemented various measures for refugee's protection in a form of relief packages to mapping protocols. The paper examines what COVID-19 and climate change crises reveal about the prevailing and anticipated challenges of refugees and displaced persons across the world and the capacity and limits of international law protection to them. The paper further explores how the global refugees' challenges during the COVID-19 pandemic could be a source for a breakthrough policy formulation with a holistic multidisciplinary approach for tackling the looming climate refugees challenge.
\end{abstract}

Keywords: Covid 19. Climate Change, Refugees, International Law, Protection.

DOI: $10.7176 / \mathrm{JLPG} / 118-04$

Publication date: February $28^{\text {th }} 2022$

\section{Introduction.}

The covid-19 pandemic created an initial drop in greenhouse gas emissions as millions of people worldwide stayed home to prevent the spread of the virus. In an ironic twist, climate change is likely to be a significant factor in the transmission of the SARS-CoV-2 virus from wildlife to humans. ${ }^{1}$ Thus, addressing climate change is essential for not only mitigating severe COVID-19 related illness and other environmental justice issues but also for limiting future viral pandemics. ${ }^{2}$

Few researchers have recently come to place the COVID-19 pandemic next to climate change because a significant reduction in local pollution has been noted since the COVID-19 outbreak, and this has led researchers to ask if this link is more than a correlation, but the former causes or helps cause the latter. The link between COVID-19 and climate change has also been analyzed albeit in different ways. Some researchers have questioned the role of climate change as one probable cause of the appearance of the virus in its transition from animals to humans.

The outbreak of COVID 19 pandemic has been a major threat to the lives of refugees and displaced people and it has also affected countries globally, raising concern from a health perspective to great socio-economic impact and variety of spillovers. The escalation of the pandemic influenced many of the marginalized communities, including the poor, the migrants, and the refugees. For refugees, the COVID-19 effect such as lockdown has raised their misery in both life and livelihood. ${ }^{3}$ According to The UN Refugee Agency, there are 71 million people involuntary moved from their country of origin, as a result of political conflicts, violence, or human rights violations. ${ }^{4}$. There are also 37,000 refugees who are forced to flee their home, on a daily basis. Over two-thirds of the world refugees today are from: Syria, Afghanistan, South Sudan, Myanmar and Somalia. ${ }^{5}$

Millions of refugees worldwide are exposed to family separation, culture loss and exile. The COVID-19 exposes these populations to a new threat, one that could prove to be more devastating than the factors forcing them to flee their homelands. One of the most unparalleled and pervasive responses to the COVID-19 public health crisis has been worldwide border closures and travel restrictions. ${ }^{6}$ These have curtailed people's

\footnotetext{
${ }^{1}$ Lein. P. J, et al, Climate Change, Environmental Justice, And Covid-19: The Perfect Storm, University of California, Davis.

${ }^{2}$ Ibid

${ }^{3}$ Buheji. M, Mavrić. B, Beka. G, Yein. T. C, (2020), Alleviation of Refugees COVID-19 Pandemic Risks- A Framework for Uncertainty Mitigation, International Business Research; Vol. 13, No. 7.

${ }^{4}$ UNHCR. (2019, June 19). The UN Refugee Agency. https://www.unhcr.org/en-us/figures-at-a-glance.html Retrieved May 2021.

${ }^{5}$ Volkin, S. (2020). How Are Refugees Affected by Covid-19? John Hopkins Magazine.

${ }^{6} \mathrm{https}$ ://www.who.int/bulletin/volumes/98/8/20-271080.pdf (Retrieved on 1st Feb 2022)
} 
movement across the globe, creating inconvenience for many but potentially life-threatening risks for refugees. The prevention of cross-border movement which is a threshold requirement for legal recognition as a refugee presents a fundamental challenge for the international protection regime. ${ }^{1}$

The mobility challenges posed by the COVID-19 pandemic sound an alarm bell for another context as well. As the Secretary General of the Pacific Islands Forum observed so astutely: 'The COVID-19 public health emergency and its ensuing humanitarian and economic fallout offers us a glimpse of what the global climate change emergency can become. if it is left unchecked and if we do not act now' ${ }^{2}$ while the risks may be less imminent, they are no less profound. ${ }^{3}$

It is uncertain how countries will receive refugee and displaced people after the COVID-19 pandemic along with other local, regional, and international organizations and NGOs to provide humanitarian support and development for them. ${ }^{4}$ Refugees can be dyed as a new political dimension in world politics after the COVID-19 pandemic which can reshape the human and political geography in and outside of the sovereign polity. However, COVID-19 pandemics again indicate the synergistic performances from the government and within the government around the world. Because the causes of conflict are much the same as they were in the past however is that the world reacts to the conflict very differently. ${ }^{5}$ It is also evident that access to the international protection regime has also become more restrictive in recent years, with western states erecting ever greater physical and bureaucratic barriers.

It is also necessary for those who are engaged in managing the trajectory of refugee and displaced people and the COIVID-19 pandemic on regional and global level needs to pay an immediate attention to the needs of ethnic, racial, indigenous and migrant minority groups ${ }^{6}$ including the large number of refugees. The existing predicament not only forced us to accept the tragedies but also offers opportunities for policy makers and researchers to investigate innovation and adaptation for future crisis management. Therefore, based on the argument that climate change and COVID-19 share a similar structure and that their policy responses follow the same format, some insights derived from the COVID-19 experience may be relevant for climate change policy formulation

\section{Putting Climate Change next to COVID-19.}

The main reason for putting climate change next to COVID-19 is because the two problems are conceptually similar, as both can be characterized as global public nuisance and as negative externalities. ${ }^{7}$ Climate change is a global externality and so is COVID-19, as contagion is a transboundary phenomenon. As a matter of fact, COVID-19 is akin a transboundary pollution problem, originating in one country but able to cause damage in another country's environment, by crossing borders through pathways like water or air. ${ }^{8}$

Climate change is a problem for the entire planet. It is global as it arises from greenhouse gas emissions, which are generated in all parts of the globe. Likewise, its impacts are felt in all world regions. COVID-19 is, in principle, a transboundary problem, because it is borne in one or more region but it can rapidly expand to the whole planet, moving from an epidemic to a pandemic.

It could be noted that the impact of climate change on a specific country is to an extent independent of its own emissions as it is evident for poor developing countries or small island states and this creates an incentive to free ride on mitigation. ${ }^{9}$ In the case of COVID-19, the extent to which one affected country can benefit from coping policies undertaken in another country seems limited. One exception is the free learning from other countries' experience in dealing with a new disease. Yet, in a globalized world where people are free to move, the impact of COVID-19 on a country does not entirely depend on its own actions to prevent it. ${ }^{10}$

It is also believed that both climate change and the COVID-19 pandemic are stock externalities with negative consequences for human wellbeing. A stock externality does not exhaust its negative impact within a single period of time, but it spreads it across time and generations. In the case of climate change, greenhouse gas stay in the atmosphere for long periods carbon dioxide for 50 to 200 years, fluorinated gases for more than

\footnotetext{
${ }^{1} \mathrm{https}$ ://www.unswlawjournal.unsw.edu.au/wp-content/uploads/2021/04/03-Foster-Lambert-McAdam.pdf (Feb 2022).

${ }^{2}$ Dame Meg Taylor, (2020), 'COVID-19 and Climate Change: We Must Rise to Both Crises', Pacific Islands Forum Secretariat

https://www.forumsec.org/2020/04/17/covid-19-and-climatechange-we-must-rise-to-both-crises/. Accessed on June 2021.

${ }^{3}$ Ibid

${ }^{4}$ Olliff, L. (2018). From Resettled Refugees to Humanitarian Actors: Refugee Diaspora Organizations and Everyday Humanitarianism. New

Political Science, 40(4), 658-674. https://doi.org/10.1080/07393148.2018.1528059. Retrieved on June 2021.

${ }^{5}$ Coker, C. (2002). Waging war without warriors? The changing culture of military conflict. Lynne Rienner

Publishers

${ }^{6}$ Bhopal, R. S. (2020). COVID-19: Immense Necessity and Challenges in Meeting the Needs of Minorities,

Especially Asylum Seekers and Undocumented Migrants. Public Health.

https://doi.org/10.1016/j.puhe.2020.04.010 (Retrieved on July 2021).

${ }^{7}$ file:///C:/Users/DELL/Downloads/sustainability-12-08560.pdf (Retrieved on 2nd Feb 2022).

${ }^{8}$ https://pdfs.semanticscholar.org/0337/028bfce065dad496abda2ebfe01fbc18478e.pdf (Retrieved on 2nd Feb 2022).

${ }^{9} \mathrm{https} / / /$ unfccc.int/resource/docs/publications/impacts.pdf (Retrieved on 2nd Feb 2022).

${ }^{10} \mathrm{https}: / /$ www.mdpi.com/2071-1050/12/20/8560/htm (Last Visited 3rd Feb 2022).
} 
thousand years so that adverse impacts affect both current and future generations. In COVID-19, the stocks of infected people increase the chances of others to be infected, increase the likelihood of health systems to collapse, which imposes external effects on the ability of new sick people to get treatment. ${ }^{1}$

The fight against the COVID-19 pandemic brings into sharp focus the balance between safeguarding public health and the economy. Parallels have been drawn between this very current policy challenge and our struggle to manage climate risks. ${ }^{2}$ There are both differences and similarities. COVID-19 represents a singular common enemy, while climate risks are more multi-faceted. It could also be argued that the time dimension also differs, with COVID-19 being more immediate whilst climate challenges often come and go with climatic events. Given the latter, oftentimes our intensity to tackle climate change also ebbs and flows. ${ }^{3}$ But despite all this, the single biggest common point is the devastation that both COVID-19 and climate change bring to our lives and livelihood. The pandemic was once a distant issue or someone else's problem. Now, everyone from China to Ghana is experiencing its full brunt. It is therefore an opportune time to reflect, reset and reprioritize. The world now has a unique opportunity to galvanize a deeper appreciation and understanding of the issues that affect us all, globally and simultaneously. Policymakers tackling the health crisis have been encouraged to pursue policies that can alleviate the economic shocks caused by the pandemic and in the same instant help address climate issues and related challenges. We can leverage the opportunity presented by the current crisis to put the world on a new trajectory with a lower risk of future climate calamities.

\section{Refugees During the COVID-19 Pandemic.}

One of the most unparalleled and pervasive responses to the COVID-19 public health crisis has been worldwide border closures and travel restrictions. These have curtailed people's movement across the globe, creating inconvenience for many but potentially life-threatening risks for would-be refugees. The prevention of cross-border movement which is a threshold requirement for legal recognition as a refugee ${ }^{4}$ presents a fundamental challenge for the international protection regime. The COVID-19 pandemic has spread into already deteriorating conditions of overpopulated refugee camps. Displaced people and host communities are the most threaten as the pandemic COVID-19 spreads. The most vulnerable ones are people situated in refugee camps, with limited access to health care, hygiene necessities and where social distancing is impossible.

The quick spread of the novel coronavirus has made practices like social or physical removing and standard hand-washing a fundamental piece of everyday life. In any case, these measures can be especially hard to try in thickly populated, casual urban settlements mainly the refugee camps where congestion makes the "two-meter division rule" practically difficult to maintain and where many needs access to fundamental administrations like water and sanitation, the chances contracting an outbreak is obvious. ${ }^{5}$

Due to lack of food and other essentials brought about by the lockdown, there are possibilities of people turning to crime such as robbery. The boats carrying Rohingyas in Malaysia has always made the citizens insecure about the share of their resources. The Rohingya refugees had to give up on their petty jobs and ways of earning a livelihood in fear of getting infected.

Refugees often share their shelter with multiple families in very density conditions which make extraordinary difficult to control spread of COVID-19. The biggest concern is on the Rohingya overpopulated refugee camp located in a dense area in Bangladesh. Moreover, in high risk are those internally displaced, such as people in Darfur, Sudan as well as Idlib, Syria; people displaced internally do not have the same right as refugees because they have been persecuted within the country of origin. ${ }^{6}$ Over $80 \%$ of the world's refugees and internally displaced people are hosted in low-income countries. The United Nations indicated that about 122 refugee host countries reported positive cases of the COVID-19. ${ }^{7}$

UNHCR, has the mandate to provide international protection to refugees, including promoting the accession to international refugee instruments and other relevant human rights instruments. UNHCR ${ }^{\text {ee }}$ s activities are also focused on assisting in the strengthening of legal structures that would enhance the rule of law, including in the area of transitional justice. But the question here lies how far an international body or a country with refugee camps has been able to cater for the needs of the refugees during this global pandemic. Its high time we strengthen the health system and access funds and other humanitarian aids to the refugees before it gets too late. The worries of the negative impact of the COVID-19 pandemic still exist as at the time of writing this paper,

\footnotetext{
${ }^{1}$ file://C:/Users/DELL/Downloads/sustainability-12-08560\%20(1).pdf (Retrieved $2^{\text {nd }}$ Feb 2022).

${ }^{2}$ https://www.bis.org/review/r200918a.pdf (Retrieved on 2nd Feb 2022).

${ }^{3}$ Ibid

${ }^{4}$ Convention Relating to the Status of Refugees, opened for signature 28 July 1951, 189 UNTS 137 (entered into

force 22 April 1954) art 1A(2) ('Refugee Convention'), read in conjunction with the Protocol Relating to the

Status of Refugees, opened for signature 31 January 1967, 606 UNTS 267 (entered into force 4 October 1967).

${ }^{5}$ MacGregor, M. (2020). COVID-19 'Crisis on top of a crisis' for refugees, aid group warns. Info Migrants.

${ }^{6}$ Volkin, S. (2020). How Are Refugees Affected by Covid-19? John Hopkins Magazine.

${ }^{7}$ UN. (2020). Scaling COVID-19 Response Protect Refugees and Migrants. https://www.un.org/en/un-coronavirus-communications-team/unscaling-covid-19-response-protect-refugees-and-migrants (Retrieved May 10 2021).
} 
however, it is not yet known whether this would carry a short-term or long-term negative impact on already vulnerable groups of refugees. This study found that large numbers of refugees reside illegally in host countries, making it difficult for them to be part of the workforce legally. Accordingly, earning their primary income by daily wages becomes more difficult or nearly impossible with lockdowns. Besides, during the pandemic, the majority of the industries and businesses around the globe stopped operating, leaving many refugees and displaced populations without access to their minimum income. ${ }^{1}$

\section{Policies for the Protection of Refugees amidst the COVID-19 and Climate Change Crises.}

The challenges posed to refugee protection by the pandemic are profound. To be a refugee, a person must have crossed an international border. This element is well established in international law, ${ }^{2}$ and a constant reminder of the limits of the refugee definition and international protection. This notion of alienage ${ }^{3}$ is also encapsulated by the principle of non-refoulement, the cornerstone of the protection regime, which prohibits removal to any place where a person faces a real risk of persecution or other serious harm. ${ }^{4}$ Hence, for refugees, mobility is an essential, even a life-saving act', ${ }^{5}$ and COVID-19 affects refugees 'at the most fundamental level. ${ }^{6}$

Refugees vulnerabilities have been further exacerbated by the impossibility of maintaining physical distancing and other COVID-19 safety measures in overcrowded camps and detention centers. ${ }^{7}$ Movement restrictions have impeded access to livelihoods and access to basic services, ${ }^{8}$ such as social protection, public health, education, child protection, income support, and social networks to manage periods of self-isolation. ${ }^{9}$ In some cases, refugees have been explicitly excluded from them. ${ }^{10}$ Yet, as UNHCR has observed, 'the virus does not distinguish between nationals or migrants, and having a two-tiered system in place to access essential medical service during this health crisis serves no one's interest'. ${ }^{11}$

Crises are not just one-off events but can encompass slower processes of change or deterioration as well. ${ }^{12}$ Understanding this is important, because it lifts our gaze beyond the here and now to contemplate policy responses over the longer-term. The challenge is to overcome the human tendency to give 'overwhelmingly higher importance to events or effects which will take place in the short term compared to the long term' ${ }^{13}$. The urgency generated by COVID-19 must help us to drive more measured, considered and sustainable policies to address the 'slow motion' crisis of climate change. ${ }^{14}$

If we think about crisis in an extended timeframe, we can identify interventions now that could avert future shocks. Many of the measures taken during the pandemic, for instance, are relevant to preparing for the impacts of climate change. ${ }^{15}$ But whereas COVID-19 has resulted in unprecedented measures of containment, the impacts of climate change will contribute to widespread displacement. Disasters, many of which are as a result of climate change ${ }^{16}$ accounted for $75 \%$ of all new global internal displacement in $2019 .{ }^{17}$ Cross-border movement is anticipated to rise as well, especially since internal displacement may transform into displacement across borders if people cannot find safety and security in their own country. ${ }^{18}$

${ }^{1}$ Volkin, S. (2020). How Are Refugees Affected by Covid-19? John Hopkins Magazine.

${ }^{2}$ Refugee Convention art $1(\mathrm{~A})(2)$

3 Andrew E Shacknove, (1985), 'Who Is a Refugee?' 95(2) Ethics 274, 283

${ }^{4}$ Refugee Convention art 33; ICCPR arts 6-7.

${ }^{5}$ Hammond. L. (2020). 'Mobility and Immobility in the Time of Coronavirus: Reflections from Long-Term Study of Migration and Displacement. (Annual Elizabeth Colson Lecture, University of Oxford, 24 June 2020) https://www.youtube.com/watch?v=DKvO1o9uM9E

${ }^{6}$ Spinks. H, (2020). 'Seeking Asylum in the Time of Coronavirus: COVID-19 Pandemic Effect on Refugees and People Seeking Asylum', Flagpost.

${ }^{7}$ Georgeou. N \& Hawksley. C (eds), (2020). State Responses to COVID-19: A Global Snapshot at 1 June 2020 (Report, 2020) 61-2, 79, 82 8 UNHCR, Global COVID-19 Emergency Response (Report, $11 \quad 3$ https://reporting.unhcr.org/sites/default/files/11082020_updated\%20UNHCR\%20Global\%20COVID- 19\%20Emergency\%20Response.pdf ('Global COVID-19 Emergency Response')

${ }^{9}$ IOM, Integrating Migration into COVID-19 Socio-Economic Response: A Toolkit for Development Partners

(Report, August 2020) <https://eea.iom.int/sites/default/files/publication/document/MMICD-ToolkitIntegrating-Migration-COVID-19Response-August.pdf $>$ ('Integrating Migration').

${ }^{10} \mathrm{Ibid}$

${ }^{11}$ Kainz. L, (2020). 'As COVID-19 Slows Human Mobility, Can the Global Compact for Migration Meet the Test for a Changed Era?', Migration Policy Institute.

${ }^{12}$ McAdam. J. 'The Problem of "Crisis Migration"” (n 2) 11-12.

${ }^{13}$ Bushell. S, et al, (2017). 'Strategic Narratives in Climate Change: Towards a Unifying Narrative to Address the Action Gap on Climate Change' 28 Energy Research \& Social Science 39, 40.

${ }^{14}$ Pierrehumbert. R. T. (2006). 'Climate Change: A Catastrophe in Slow Motion'. 6(2) Chicago Journal of International Law 573.

${ }^{15}$ Watts. N, et al, (2021). 'The 2020 Report of the Lancet Countdown on Health and Climate Change: Responding to Converging Crises' (2021) 397(10269) The Lancet 129, 131.

${ }^{16}$ McAdam. J, et al. (2016). Fridtjof Nansen Institute, International Law and Sea-Level Rise: Forced Migration and Human Rights.

${ }^{17}$ Internal Displacement Monitoring Centre ('IDMC'), 2020 Global Report on Internal Displacement (Report,

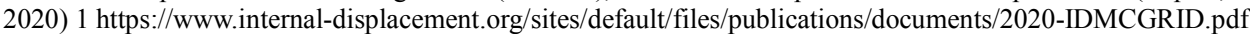

${ }^{18}$ Nansen Initiative, Agenda for the Protection of Cross-Border Displaced Persons in the Context of

Disasters and Climate Change (Report, 2015) vol 1, 39 [99]; IDMC, 2019 Global Report on Internal

Displacement (Report, 2019) $41<$ https://www.internaldisplacement.org/sites/default/files/publications/documents/2019-IDMC-GRID.pdf>; 
Existing international protection mechanisms offer an incomplete and imperfect solution for those seeking to escape the longer-term impacts of human rights violation and climate change. There are number of reasons for this, ${ }^{1}$ including that some effects will take years to manifest at a sufficiently harmful level to satisfy the requisite thresholds in international refugee law and international human rights law. ${ }^{2}$ The challenge for international lawyers and international law is whether those bodies of law can evolve dynamically to offer solutions, as they have done historically as living instruments of protection.

Certainly, as understandings of the nature of mobility in the context of human right violations, climate change and disasters have improved, our analysis of the capacity of existing frameworks to respond has become more nuanced. ${ }^{3}$ At the same time, approaching displacement solely in light of extant protection frameworks or even in terms of a treaty-based regime necessarily constrains our thinking, both conceptually and pragmatically. As Fisher, Scotford and Barritt have argued, 'the international treaty process is seen as the ultimate panacea', but there are many reasons why this alone will not provide a solution for those on the move. Addressing displacement related to the impacts of climate change and other related challenges requires a holistic, multidisciplinary, and multi-sectoral approach, which is best approached through a toolkit response that encompasses disaster risk reduction, climate change adaptation, humanitarian protection, migration, and planned relocation.

For instance, in late 2019, the UN Human Rights Committee accepted in principle that it is unlawful for states to send people to places where the impacts of climate change expose them to life-threatening risks or cruel, inhuman, or degrading treatment. ${ }^{5}$ However, in the matter at hand, the evidence did not establish that the complainant faced a risk of an imminent, or likely, risk of arbitrary deprivation of life upon return to Kiribati' ${ }^{6}$ This was despite the Committee's acknowledgment that sea-level rise was 'likely to render the Republic of Kiribati uninhabitable', potentially within the next 10 to 15 years. ${ }^{7}$ At present, there was insufficient evidence to show that the complainant would 'be unable to grow food or access potable water' or would 'face lifethreatening environmental conditions', or that 'the Government of Kiribati had failed to take programmatic steps to provide for the basic necessities of life, in order to meet its positive obligation to fulfill the complainant's right to life' ${ }^{8}$ The Committee recognized that conditions in Kiribati 'may become incompatible with the right to life with dignity before the risk is realized', ${ }^{9}$ thus tacitly acknowledging that people should not have to wait until their lives are imminently threatened before they are eligible for protection. However, it did not provide guidance as to when such a point of incompatibility might be reached.

This underscores the need for proactive policies to help build resilience within affected communities and provide lawful opportunities for movement. While the current rate of global warming means that some displacement is inevitable ${ }^{10}$. A World Bank Report posits that robust mitigation and adaptation measures could cut global internal displacement by almost two-thirds by $2050 .{ }^{11}$ Indeed, mitigation may be understood as the climate change equivalent of a COVID-19 vaccine. In addition, disaster risk reduction, increased opportunities for lawful migration, more systematic humanitarian responses to displacement, and selective planned relocations could help avert future displacement and enable people to make real choices about whether they stay in their homes, or move elsewhere.

The climate crisis is an unfolding process, and interventions must be taken into consideration over longer time period, with new combinations of the necessary organizations. Indeed, without such interventions, the climate crisis 'could prove far lengthier and far more disruptive than what we currently experiencing with covid $19 .{ }^{12}$ The challenge lies in generating support for policy change now to avert devastating consequences in the future. Whereas with COVID-19, 'the consequences from inaction can be seen relatively quickly, as hospitals

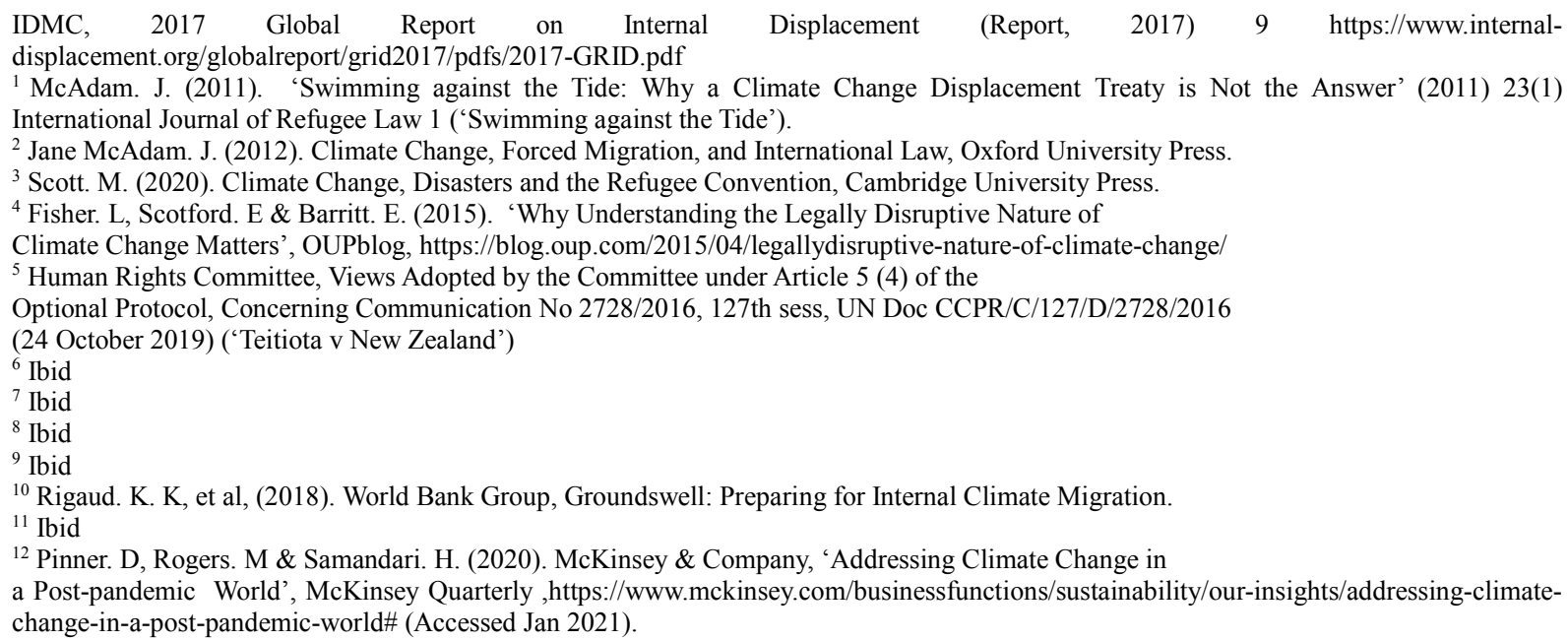


are overwhelmed by patients infected several weeks ago', with climate change, 'it will take decades to see the full extent of the damage'. ${ }^{1}$ On the one hand, this longer timeframe offers an opportunity for greater international cooperation towards a coherent response than emergency measures allow.

\section{Conclusion}

The year 2020 has brought into sharp focus the inextricable connections between climate change, and COVID19. Evidence that people in polluted areas are far more likely to die from COVID-19 than those living in cleaner areas provides compelling rationale to not only enforce, but also strengthen, environmental pollution regulations, and for humans globally to embrace lifestyle and policy changes that mitigate climate change to the greatest extent possible. Refugees and displaced people usually tend to have a higher rate of underlying physical and mental health conditions due to the impacts of war, disease and famine, making them more susceptible to be infected to COVID-19.

It will be essential to develop an inclusive legal framework that advocates for all people highlights how injustices happening to marginalized communities are interconnected with the degradation and poisoning of places where they live, work, and play. As we struggle to overcome the complex issues associated with climate change, and COVID-19, we must keep in mind that the solution to the next viral may be locked in the brain of a child living in a deprived community experiencing higher levels of environmental pollution that limits not only their potential but also society's benefit from their contribution.

In many ways, the COVID-19 outbreak is a warning about future socio-economic disturbances that we may face with climate change. We can use the lessons learned from this crisis to open opportunities for addressing critical gaps in community resilience by integrating sustainability, health imperatives, and climate objectives through long-term integrated planning.

Both climate change and Covid 19 adaptation can be framed as part of countries' legal obligation to realize the right to health through their laws, policies and budgets. Under international human rights instruments, such as the International Covenant on Economic, Social and Cultural Rights, countries have obligations to respect, protect and fulfil the right to health, including taking steps to prevent pandemic. The Paris Agreement acknowledges that in taking action to address climate change, countries should consider, respect and promote their obligations on the right to health. Robust global cooperation and governance with a human rights-centered approach supported by appropriate legal and institutional frameworks is a prerequisite for successfully confronting these multi-dimensional, overlapping challenges with integrated solutions.

This paper has shown the continuing relevance of the Refugee Convention and other human rights treaties in the context of emergencies such as COVID-19, in particular, by acknowledging the legitimate interests of states in refugee protection. However, when faced with a crisis that is unfolding over a longer timeframe, such as climate change, the question is whether this body of law will evolve dynamically beyond emergency measures to greater international cooperation, without losing the sense of urgency and making it a problem for the future alone. It is also important that the narrative of crisis does not lead to paralysis because the policy challenges are perceived as insurmountable. ${ }^{2}$ For this reason, emphasizing proactive measures that can avert future catastrophes as detailed in the preceding section may engender a more solutions-oriented approach.

As the UNHCR has noted, it is only by respecting human rights that 'we will build better responses for the emergency today and solutions for recovery in the longer term'. ${ }^{3}$ This requires greater international collaboration, responsibility-sharing and cooperation, as promised by states when they adopted the twin Global Compacts on Refugees and Migration in late 2018. ${ }^{4}$ To date, however, these commitments have not withstood the pandemic crisis, despite efforts by the UNHCR, IOM, and others to show how these instruments can assist, rather than hinder, responses. Whether this is a temporary aberration or hardens into a permanent pattern remains to be seen. COVID-19 has demonstrated that a 'large-scale, comprehensive response' is 'the only way to withstand and manage any future unprecedented health and climate crises, and that we do, in fact, have 'the technology, scientific understanding, financial means and human resourcefulness' needed to address it. ${ }^{5}$

\section{References.}

Andrew E Shacknove, (1985), 'Who Is a Refugee?' 95(2) Ethics 274, 283.

\footnotetext{
${ }^{1}$ Andrew Kliewer. A. (2020). 'Climate Change is Coronavirus in Slow Motion', Age of Awareness https://medium.com/age-ofawareness/climate-change-is-coronavirus-in-slow-motion-b8932f8e2905 (Retrieved April 2020).

${ }^{2}$ McAdam, J. 'The Problem of "Crisis Migration"” (n 2) 23.

3 'The Role of the Global Compact' (n 48) 2.

${ }^{4}$ United Nations, Report of the United Nations High Commissioner for Refugees: Part II Global Compact on Refugees, UN Doc A/73/12 (Part II) (2 August 2018); Global Compact for Safe, Orderly and Regular Migration, GA Res 73/195, UN GAOR, 73rd sess, Agenda Items 14 and 119, UN Doc A/RES/73/195 (11 January 2019)

${ }^{5}$ Metzke. R. (2020). 'Climate Action Must Stay Top of the Global Agenda as We Emerge from COVID-19', World Economic Forum, https://www.weforum.org/agenda/2020/05/climate-action-topglobal-agenda-covid-19/(Retrieved May 2020).
} 
Andrew Kliewer. A. (2020). 'Climate Change is Coronavirus in Slow Motion', Age of Awareness https://medium.com/age-of-awareness/climate-change-is-coronavirus-in-slow-motion-b8932f8e2905 (Retrieved April 2020).

Baloch, A. (2007). The Economic effects of Refugees crises on neighbouring host countries: Emphirical evidence from Pakistan.

Bhopal, R. S. (2020). COVID-19: Immense Necessity and Challenges in Meeting the Needs of Minorities, Especially Asylum Seekers and Undocumented Migrants. Public Health. https://doi.org/10.1016/j.puhe.2020.04.010 Retrieved on July 2021).

Buheji. M, Mavrić. B, Beka. G, Yein. T. C, (2020), Alleviation of Refugees COVID-19 Pandemic Risks- A Framework for Uncertainty Mitigation, International Business Research; Vol. 13, No. 7.

Bushell. S, et al, (2017). 'Strategic Narratives in Climate Change: Towards a Unifying Narrative to Address the Action Gap on Climate Change' 28 Energy Research \& Social Science 39, 40.

Coker, C. (2002). Waging war without warriors? The changing culture of military conflict. Lynne Rienner Publishers

Dame Meg Taylor, (2020), 'COVID-19 and Climate Change: We Must Rise to Both Crises', Pacific Islands Forum Secretariat https://www.forumsec.org/2020/04/17/covid-19-and-climatechange-we-must-rise-toboth-crises/. Accessed on June 2021.

Fisher. L, Scotford. E \& Barritt. E. (2015). 'Why Understanding the Legally Disruptive Nature of Climate Change Matters', OUPblog https://blog.oup.com/2015/04/legallydisruptive-nature-of-climatechange/Human Rights Committee, Views Adopted by the Committee under Article 5 (4) of the Optional Protocol, Concerning Communication No 2728/2016, 127th sess, UN Doc CCPR/C/127/D/2728/2016. (24 October 2019) ('Teitiota v New Zealand').

Georgeou. N \& Hawksley. C (eds), (2020). State Responses to COVID-19: A Global Snapshot at 1 June 2020 (Report, 2020) 61-2, 79, 82

Hammond. L. (2020). 'Mobility and Immobility in the Time of Coronavirus: Reflections from Long-Term Study of Migration and Displacement. (Annual Elizabeth Colson Lecture, University of Oxford, 24 June 2020) https://www.youtube.com/watch?v=DKvO109uM9E

Human Rights Committee, Views Adopted by the Committee under Article 5 (4) of the Optional Protocol, Concerning Communication No 2728/2016, 127th sess, UN Doc CCPR/C/127/D/2728/2016 (24 October 2019) ('Teitiota v New Zealand').

Internal Displacement Monitoring Centre ('IDMC'), 2020 Global Report on Internal Displacement (Report, 2020) $\quad 1 \quad \mathrm{https}: / / w w w . i n t e r n a l-d i s p l a c e m e n t . o r g / s i t e s / d e f a u l t / f i l e s / p u b l i c a t i o n s / d o c u m e n t s / 2020$ IDMCGRID.pdf

IOM, Integrating Migration into COVID-19 Socio-Economic Response: A Toolkit for Development Partners (Report, August 2020) <https://eea.iom.int/sites/default/files/publication/document/MMICDToolkitIntegrating-Migration-COVID-19-Response-August.pdf ('Integrating Migration').

Kainz. L, (2020). 'As COVID-19 Slows Human Mobility, Can the Global Compact for Migration Meet the Test for a Changed Era?', Migration Policy Institute.

Lein. P. J, et al, Climate Change, Environmental Justice, And Covid-19: The Perfect Storm, University of California, Davis.

MacGregor, M. (2020). COVID-19 'Crisis on top of a crisis' for refugees, aid group warns. Info Migrants.

McAdam, "The Problem of "Crisis Migration"' (n 2) 11-12.

McAdam. J, et al. (2016). Fridtjof Nansen Institute, International Law and Sea-Level Rise: Forced Migration and Human Rights.

McAdam. J. (2011). 'Swimming against the Tide: Why a Climate Change Displacement Treaty is Not the Answer' (2011) 23(1) International Journal of Refugee Law 1 ('Swimming against the Tide').

McAdam. J. (2012). Climate Change, Forced Migration, and International Law, Oxford University Press.

Metzke. R. (2020). 'Climate Action Must Stay Top of the Global Agenda as We Emerge from COVID-19', World Economic Forum, https://www.weforum.org/agenda/2020/05/climate-action-topglobal-agendacovid-19/ (Retrieved May 2020).

Nansen Initiative, Agenda for the Protection of Cross-Border Displaced Persons in the Context of Disasters and Climate Change (Report, 2015) vol 1, 39 [99]; IDMC, 2019 Global Report on Internal Displacement (Report, 2019) $41<\mathrm{https} / /$ www.internaldisplacement.org/sites/default/files/publications/documents/2019IDMC-GRID.pdf> IDMC, 2017 Global Report on Internal Displacement (Report, 2017) 9 https://www.internal-displacement.org/globalreport/grid2017/pdfs/2017-GRID.pdf

Olliff, L. (2018). From Resettled Refugees to Humanitarian Actors: Refugee Diaspora Organizations and Everyday Humanitarianism. New Political Science, 40(4), 658-674. https://doi.org/10.1080/07393148.2018.1528059

Pierrehumbert. R. T. (2006). 'Climate Change: A Catastrophe in Slow Motion'. 6(2) Chicago Journal of 
International Law 573.

Pinner. D, Rogers. M \& Samandari. H. (2020). McKinsey \& Company, 'Addressing Climate Change in a Postpandemic World', McKinsey Quarterly ,https://www.mckinsey.com/businessfunctions/sustainability/ourinsights/addressing-climate-change-in-a-post-pandemic-world\# (Accessed Jan 2021).

Rigaud. K. K, et al, (2018). World Bank Group, Groundswell: Preparing for Internal Climate Migration.

Root, R. (2020). Here What the COVID-19 Response Looks Like in Refugee Camps. Retrieved May 10, 2020, from https://www.devex.com/news/here-s-what-the-covid-19-response-looks-like-in-refugee-camps-96874 (Accessed on Oct 2021).

Scott. M. (2020). Climate Change, Disasters and the Refugee Convention, Cambridge University Press.

Spinks. H, (2020). 'Seeking Asylum in the Time of Coronavirus: COVID-19 Pandemic Effect on Refugees and People Seeking Asylum', Flagpost

The Role of the Global Compact' (n 48) 2.

UN. (2020). Scaling COVID-19 Response Protect Refugees and Migrants. https://www.un.org/en/uncoronavirus-communications-team/un-scaling-covid-19-response-protect-refugees-and-migrants (Retrieved May 10 2021).

UNHCR, Global COVID-19 Emergency Response (Report, 11 August 2020) 3 https://reporting.unhcr.org/sites/default/files/1 1082020 updated\%20UNHCR\%20Global\%20COVID19\%20Emergency\%20Response.pdf ('Global COVID-19 Emergency Response')

UNHCR. (2019, June 19). The UN Refugee Agency. https://www.unhcr.org/en-us/figures-at-a-glance.html Retrieved May 2021.

United Nations, Report of the United Nations High Commissioner for Refugees: Part II Global Compact on Refugees, UN Doc A/73/12 (Part II) (2 August 2018); Global Compact for Safe, Orderly and Regular Migration, GA Res 73/195, UN GAOR, 73rd sess, Agenda Items 14 and 119, UN Doc A/RES/73/195 (11 January 2019).

Volkin, S. (2020). How Are Refugees Affected by Covid-19? John Hopkins Magazine.

Watts. N, et al, (2021). 'The 2020 Report of the Lancet Countdown on Health and Climate Change: Responding to Converging Crises' (2021) 397(10269) The Lancet 129, 131. 